\title{
Laboratory interference in the thyroid function test
}

\author{
Katarzyna Paczkowska ${ }^{\circledR 1}$, Anna Otlewska', Olga Loska², Katarzyna Kolačkov ${ }^{\circledR 1}$, Marek Bolanowski®1, \\ Jacek Daroszewski 1
}

${ }^{1}$ Department of Endocrinology, Diabetes, and Isotope Therapy, Wroclaw Medical University, Wroclaw, Poland

${ }^{2}$ Department of Forensic Medicine, Wroclaw Medical University, Wroclaw, Poland

\begin{abstract}
Thyroid hormones and thyroid-stimulating hormone (TSH) laboratory tests are commonly used worldwide, and their results have an important influence on decisions about treatment and further diagnostic processes.

Any discrepancies between symptoms and laboratory results or between results of different tests should be closely investigated to avoid misdiagnosis and unnecessary treatment.

Inconsistencies in hormone tests might be a result of physiological changes in hormonal balance, a disease, drug intake, or laboratory interference. Major factors that interfere with thyroid function tests are: heterophilic antibodies, macro TSH, biotin, thyroid hormones autoantibodies, anti-streptavidin, and anti-ruthenium antibodies.

In this paper we discuss the influence of different factors on the procedures of hormonal immunoassays, as well as methods to minimise the risk of false results and misdiagnoses. (Endokrynol Pol 2020; 71 (6): 551-560)

Key words: thyroid function test; laboratory interference; immunoassay
\end{abstract}

\section{Introduction}

Thyroid hormones (THs) and thyroid-stimulating hormone (thyrotropin, TSH) laboratory tests are commonly used worldwide for the assessment of thyroid function. According to data from 2013, TSH tests were ordered 59 million times in the US during a year. [1] The results of thyroid function tests have an important influence on decisions about treatment and further diagnostic processes. When results are combined with symptoms, determination of whether a patient is euthyroid or suffers from hypo- or hyperthyroidism is usually simple for clinicians. However, there are a group of patients whose diagnostic process is challenging due to the discrepancies between the results of hormone tests and symptoms or because results are inconsistent with each other.

Inconsistencies in hormone tests might be a result of physiological changes in hormonal balance (e.g. pregnancy) [2], a disease (non-thyroidal or thyroid disorders) [3], drug intake (e.g. amiodarone, contrast agents) [4], or laboratory interference (e.g. with heterophilic antibodies) [5]. All of the above possibilities should be taken into consideration before performing more invasive diagnostic tests or before starting a treatment.

In this paper we discuss the influence of different factors on the procedures of hormonal immunoassays as well as methods to minimise the risk of false results and misdiagnoses.

\section{Overview of laboratory methods in TSH and thyroid hormone tests}

An assessment of thyroid function is mainly based on the measurement of free thyroid hormones and thyrotropin concentrations, in the form of thyroid function tests (TFTs). These hormones are most often determined by immunochemical methods, in which an antigen-antibody interaction is used. Affinity between a paratope of the antibody Fab fragment and a unique determinant of the antigen molecule leads to form an antigen-antibody complex (Ag-Ab) [6]. The immunochemical methods, depending on the principle of the test, may be divided into two groups: competitive and non-competitive [7]. Figures 1A, 1B, and 2 present diagrams of competitive and non-competitive methods with possible interferences and places where they act.

Competitive methods may differ between companies (Fig. 1A and 1B). Figure 1a presents an assay in which antibodies against an analyte (e.g. hormone) are added to the patient's serum with a known amount of the labelled analogue. This action induces competition between an antigen present in patient's plasma 


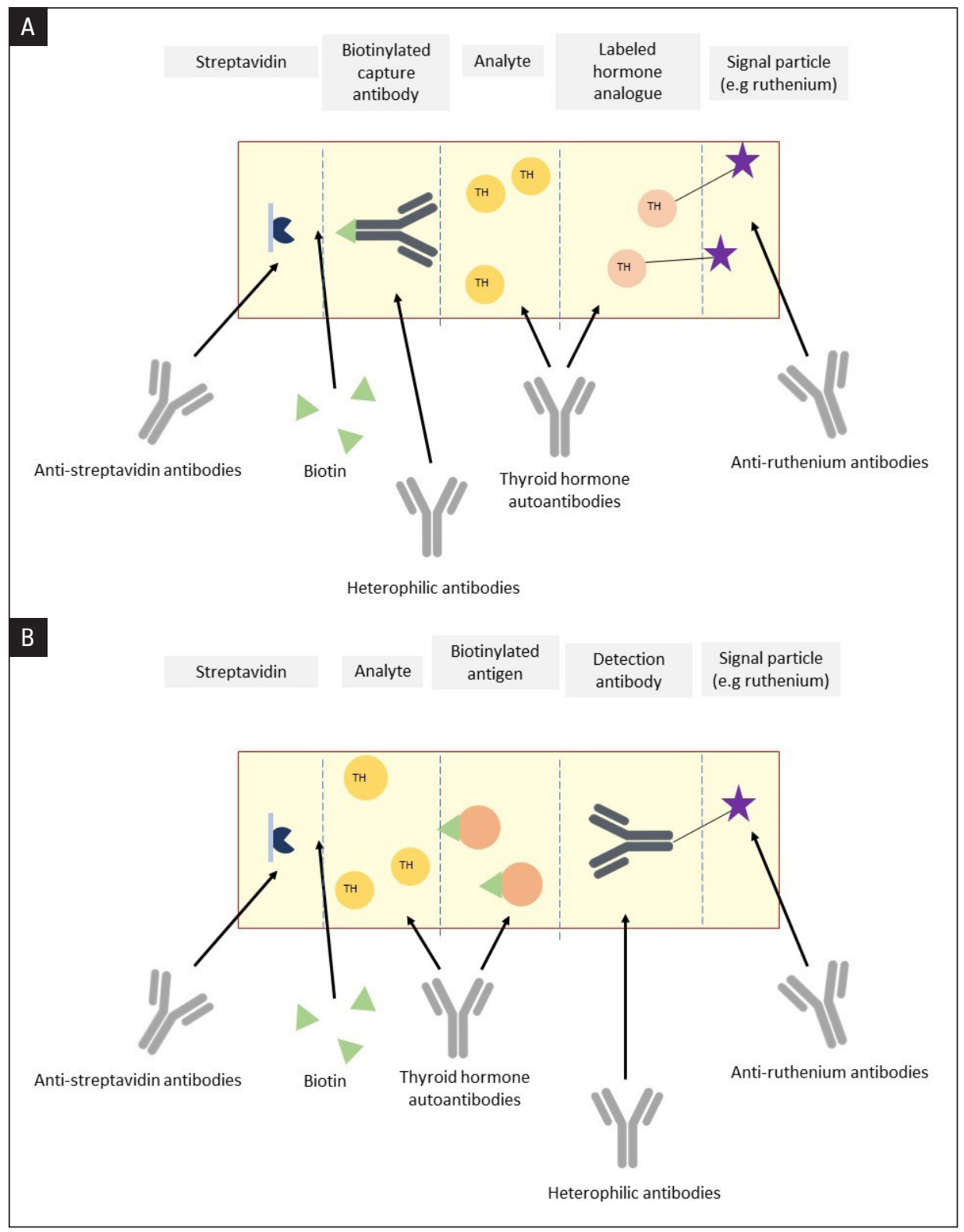

Figure 1AB. Two types of competitive methods and possible interferences (indicated by arrows)

and a prepared, labelled antigen - they compete for a limited number of antibody binding sites. The amount of the formed "labelled antigen-antibody" complex is inversely proportional to the concentration of the analyte [8]. Other assay procedures include incubation of labelled antibodies with patient's serum and then addition of biotinylated antigen (or analogue) and streptavidin-coated microparticles to the mixture (Fig. 1B). Complexes of biotinylated antigen and labelled antibodies are captured on the surface of the electrode. The intensity of the signal is also inversely proportional to the concentration of the analyte $[9,10]$. Measurement of fT4 and fT3 is an example of using a competitive assay in the laboratory $[7,8]$.

Non-competitive binding assays use two types of antibodies: capture and labelled. The first one is usu- ally coated on a solid phase and captures the analyte particles that have a specific epitope on their surface. A conjugate, i.e. a suspension of labelled (signal) antibodies, is then added to the reaction mixture [8]. These antibodies bind to another fragment of the tested molecule, forming the so-called sandwich assay (combination of the capture antibody-antigen-labelled antibody) (Fig. 2). Non-competitive assay is used for a TSH measurement [11].

As mentioned before, tracers are used in immunochemical methods to generate a signal. Sensitive detection of even very low concentrations of measured parameters is possible. Nowadays, a wide range of labels are used in the immunochemical methods. First of all, the isotope labels that enable radioactivity measurement (RIA — radioimmunoassays) can be distinguished [12]. Currently, 


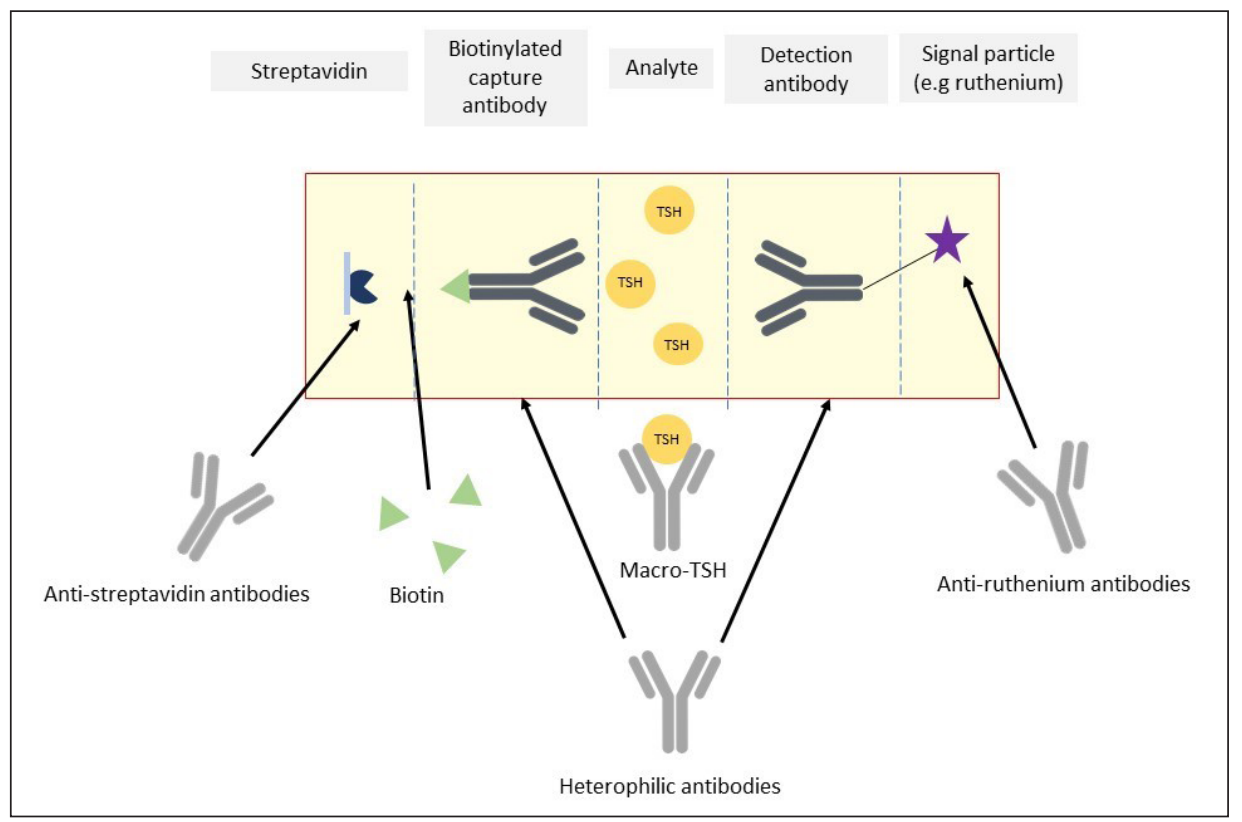

Figure 2. Non-competitive method and possible interferences (indicated by arrows)

Table 1. Summary of major interferences and their possible effects on thyroid function test results

\begin{tabular}{lcccccc}
\hline Interference & TSH & fT4 & fT3 & other & Prevalence \\
\hline Heterophile antibodies & $\uparrow$ or $\downarrow$ & $\uparrow$ or $\downarrow$ & $\uparrow$ or $\downarrow$ & Most assays may be affected & $0.05-6 \%$ \\
\hline Macro TSH & $\uparrow$ & - & - & & $\begin{array}{c}0.6-1.6 \% \text { in patients with subclinical } \\
\text { hypothyroidism }\end{array}$ \\
\hline Biotin & $\mathrm{N}$ or $\downarrow$ & $\uparrow$ & $\uparrow$ & $\begin{array}{c}\text { Anti-TSHR } \uparrow, \text { anti-TPO } \uparrow \text {, anti-TG } \uparrow \\
\text { and other hormonal assays }\end{array}$ & $\begin{array}{c}\text { Not estimated in general population, } \\
\text { related to the dosage of biotin intake }\end{array}$ \\
\hline $\begin{array}{l}\text { Anti-streptavidin } \\
\text { antibodies }\end{array}$ & $\mathrm{N}$ or $\downarrow$ & $\uparrow$ & $\uparrow$ & Anti-TSHR $\uparrow$, anti-TPO $\uparrow$, anti-TG $\uparrow$ & Few cases described \\
\hline Anti-ruthenium antibodies & $\uparrow$ or $\downarrow$ & $\uparrow$ or $\downarrow$ & $\uparrow$ or $\downarrow$ & & Few cases described \\
\hline $\begin{array}{l}\text { Thyroid hormones } \\
\text { autoantibodies }\end{array}$ & - & $\uparrow$ & $\uparrow$ & - & $1.8 \%$ \\
\hline
\end{tabular}

anti-TSHR — antibodies against TSH receptor; anti-TPO — antibodies against thyroid peroxidase; anti-TG — antibodies against thyroglobulin

they are rarely used in routine laboratory diagnostics, mostly due to the non-automatic methodology. Other types of labels are enzymatic ones (EIA - enzyme immunoassay). Enzymes catalyse the specific dye reaction, and the product is quantified spectrophotometrically [13]. In immunofluorometric (FIA - fluorescent immunoassay) methods, substances with fluorescent properties are used as a label. They radiate fluorescence by the absorption of an appropriate wavelength of light [14]. When labels emit the light due to the energy produced in a chemical reaction, it is called the chemiluminescent assay (CLA) [15]. Other types of assays use electrochemiluminescence methods (ECLIA - electrochemiluminescence immunoassay), in which chemiluminescence is initiated by electrochemical reactions. Highly reactive substances are formed from their stable precursors, e.g. ruthenium chelates, on the electrode surface [16].
Competitive methods for the determination of usually low-molecular-weight analytes, such as fT3 and fT4, as well as non-competitive methods used for the analysis of high-molecular-weight antigens, require separation of the resulting complexes from the reaction mixture. Depending on the manufacture of the test, these isolations proceed in different ways, the most popular being the biotin-streptavidin/-avidin system for this purpose.

Streptavidin is a glycoprotein with high affinity to biotin. Biotin is a low-weight (244.31 Da), water-soluble vitamin, essential for enzymes needed in different metabolic reactions in the human body $[17,18]$. The streptavidin and biotin interactions have some unique characteristics that enable them to be widely used in immunochemical tests. This interaction is very specific, characterised by a strong affinity 
and resistance to various manipulations during the test procedure, such as: rinsing, $\mathrm{pH}$ or temperature change, and the use of denaturing substances [18, 19]. An advantage of this system is also the fact that biotin does not change the properties of the molecules to which it is attached. It is also small enough to be used in measurements of small molecules, e.g. thyroid hormones, because, in most cases, it does not change their bioactivity, such as the ability to bind the antibody [18]. Streptavidin or avidin are often used as a conjugate in combination with labels. The biotin-streptavidin/-avidin system is not directly a measured signal, but it is a high-affinity separation method that increases the test sensitivity.

The development of immunochemical techniques, the use of specific labels, and the constant improvement of test procedures have increased the sensitivity of the analytical measurement of thyrotropin. First-generation tests (usually RIA) had a detection limit of 1-2 $\mu \mathrm{IU} / \mathrm{mL}$, second-generation tests (usually ELISA) improved it to $0.1-0.2 \mu \mathrm{IU} / \mathrm{mL}$, while third-generation tests a reached functional sensitivity of $0.01-0.02 \mu \mathrm{IU} / \mathrm{mL}$ [20]. The third-generation assays are the most widely used in routine practice. Currently, many companies offer fourth-generation tests with measurement sensitivity of up to $0.001 \mu \mathrm{IU} / \mathrm{mL}$ [21].

\section{Laboratory interferences}

There are two types of laboratory interference: positive, which leads to a falsely elevated test result, and negative, when a test result is falsely decreased [11]. The immunoassay may be affected at all stages of measurement by different factors, and the major ones are as follows: heterophilic antibodies, macro TSH, biotin, anti-streptavidin, anti-ruthenium antibodies, and thyroid hormones autoantibodies (Fig. 1A, 1B, and 2).

Misdiagnosis caused by laboratory interference is an important problem, and laboratory test results should always be correlated with signs and symptoms before interpretation. Large numbers of patients looking for advice from an endocrinologist because of slight, subjective complaints that may have different background represent a challenging problem. When hormonal disturbances are taken into consideration in these subjects, results of hormonal tests must be interpreted with extra care. Favresse et al. analysed the clinical consequences in more than 150 cases of laboratory interference published between 1981 and 2017. Only in $8 \%$ of cases was there no clinical impact, and in $42 \%$ of cases it was not determined. The negative clinical consequences were observed in approximately half of patients, including the following: inappropriate L-thyroxine or antithyroid drug treatment, radioactive scans, additional hormonal tests, and delays in diagnosis and treatment [22].

\section{Heterophile antibodies (HA)}

The presence of antibodies in several patients' blood, which interfere with an immunoassay, is still unrecognized and unresolved problem. These antibodies react with an analyte or with the antibodies used in the assay (capture and detection), and they cause false results. The reaction between an analyte (e.g. hormone) and serum antibodies may occur, which leads to blockage of the reaction between analyte molecules and detection antibodies - negative interference occurs, and the result is lower than should be. When positive interference occurs, interfered antibodies bind to detection antibodies in the assay and the result is overvalued [23].

Laboratory interferences with heterophile antibodies in the immunoassay seem to be an irrelevant problem in everyday clinical practice because of their rare occurrence - their prevalence was estimated from 0.05 to $6 \%$, depending on the assay $[24,25]$. There is a possibility to reduce this number using blocking reagents [26]. However, this problem becomes important when we think about consequences of misdiagnosis. The ratio of misdiagnosed patients is higher than the number of laboratory interferences because it takes into account the prevalence of the disease. That statistical problem was illustrated on the example of subclinical hypothyroidism, in which confrontation of TFTs with clinical presentation is especially difficult. The prevalence of the disease (true positive test result) in the population was estimated at approximately $2 \%$, and the prevalence of laboratory interferences in the TSH immunoassay was estimated at $0.4 \%$ [27]. In conclusion, approximately $17 \%$ of patients diagnosed with subclinical hypothyroidism may suffer from "phantom disease"; they do not have any thyroid disfunction, the problem is only falsely elevated serum TSH level (false positive test result) [28]. Taking into account the wide access to TFTs in the Polish population, the problem of misdiagnosis may be more serious.

It is worth remembering that laboratory interference occurs not only in hormonal analysis. Thyroglobulin (Tg) measurements are used in the follow-up of patients after treatment for differentiated thyroid cancer as a marker of tumour recurrence [29]. Any disturbances in the results, either falsely elevated or decreased, may have important clinical consequences. In different studies, the prevalence of interferences with heterophile antibodies in $\mathrm{Tg}$ measurement was estimated at approximately 1-2\% [30]. However, this problem seems to be well-recognised in our professional society.

Antibodies that interfere with laboratory testing by binding assay antibodies are usually called heterophile 
antibodies; however, the definition is interpreted differently by several authors. In this paper we consider heterophile antibodies as a group of antibodies affecting immunoassays in similar way, but in the literature they are divided into three main subgroups: human anti-animal antibodies (HAAAs), rheumatoid factor, and heterophile antibodies with unknown exposure to antigen [31]:

- HAAAs are monospecific, high-affinity antibodies. They are produced by the patient's immunological system in response to injection of animal antibodies, usually given for diagnostic or treatment reasons [32]. There are different types of HAAAs, such as: anti-goat, anti-rabbit, anti-sheep antibodies. The majority of antibodies used for medical purposes (e.g. in biological treatment) are obtained from mice, which is why human anti-mouse antibodies (HAMAs) are the most common anti-animal antibodies detected in human blood [33, 34]. Anti-mouse antibodies are also often used in immunoassays, and the presence of HAMAs in patient serum results in important interferences:

- rheumatoid factor (RF) are antibodies (usually IgM) found in approximately $70 \%$ of patients with rheumatoid arthritis; RF is also present in approximately $5-10 \%$ of the healthy population [35]. Rheumatoid factor has affinity to the human Fc-region of immunoglobulin $\mathrm{G}(\operatorname{IgG})$ and the animal Fc-region of antibodies that is similar to the human one, which is why RF may bind the assay's antibodies and interfere with analysis. There are reported case studies of abnormal titres of thyroglobulin, calcitonin, fT4, or TSH due to interferences with RF [29, 36-38];

- heterophile antibodies with unknown exposure are common, and they are found in as much as $40 \%$ of the general population. There are different types of those antibodies, but most of them do not affect immunoassays. The most problematic ones are those with affinity to the Fc-region of anti-mouse IgG1 antibodies [31].

Identification of interferences in an immunoassay is a difficult, time-consuming process. A single test is rarely sufficient to evaluate the interferences. In order to identify interferences with heterophile antibodies in approximately $90 \%$ of suspected serum samples, three independent tests should be used [39]. First of all, an analysis should be repeated with an alternative method or on a different test platform, but the interference may be present in both analyses. Another test is a serial dilution: in samples where interference occurs there is a lack of linearity and parallelism, but this is found only in $60 \%$ of affected samples. The third test is an analysis of the serum sample after incubation with commercial blocking antibodies. A significant difference in results before and after incubation is evidence of the presence of interference. The sensitivity of this method is estimated at approximately $70-80 \%$. In order to improve the detection of interferences in testing samples, all three tests should be performed when discrepancies in results due to heterophile antibodies are suspected.

There are few methods used to neutralise or remove interfered antibodies and to measure the true concentration of an analyte.

Adding commercial blocking antibodies is not only a test for interference, but it might lead to neutralisation of heterophile antibodies before measurements. As was mentioned before, this procedure would be sufficient only in $70-80 \%$ of samples. Another method to neutralise interfering antibodies is the incubation of the patient's blood sample with animal immunoglobulin before an immunoassay (e.g. if we consider the presence of HAMA, incubation with mouse immunoglobulins may neutralise heterophile antibodies) [40].

Polyethylene glycols (PEG) precipitate proteins, including immunoglobulin, and lead to serum purification from interfering antibodies [41]. This method has limitation and cannot be used in measurement of immunoglobulins (i.e. concentration of anti-TSH receptor antibodies) and is not useful in the precise assessment of TSH levels because $35-40 \%$ of TSH is destroyed during PEG precipitation [42].

When identification of antibodies present in serum sample is necessary, Protein G columns may be used. In this method, human IgG are isolated from serum, but they are not denatured and may be identified in other tests [31].

\section{Macro TSH}

Macro TSH is formed by TSH molecules bound to anti-human TSH autoantibodies [43, 44]. It is a large molecule with molecular weight of $150 \mathrm{kDa}$ or more. In comparison, one TSH molecule is $28 \mathrm{kDa}[22,44]$. The size of macro TSH increases the possibility of the accumulation of those molecules in circulation, which leads to falsely elevated results of TSH measurements. It is speculated that macro TSH molecules have low bioactivity $[43,45]$. It seems that patients with confirmed presence of macro TSH and free TSH levels within the reference range do not require hormone replacement therapy (HRT). All these features of macro TSH resemble macroprolactin, detected in approximately 9.7-29\% of patients diagnosed with hyperprolactinaemia [46].

The cause of the formation of anti-TSH antibodies is still unknown. [44] The occurrence of macro TSH should be suspected in patients without any symptoms of thyroid disease but with elevated TSH levels and fT3 and fT4 within the reference range in laboratory tests. This clinical picture is similar to diagnosis of subclinical hy- 
pothyroidism. On the basis of the data from a relatively large series of subjects, the prevalence of macro TSH among patients with subclinical hypothyroidism has been estimated at $0.6-1.6 \%[43,47]$.

Hormone replacement therapy for subclinical hypothyroidism is usually started when the TSH level is $10 \mathrm{mIU} / \mathrm{L}$ or more, according to the last official recommendations [48, 49]. The therapy is continued lifelong; hence, it is crucial to differentiate the cause of elevated TSH levels between monomeric TSH and macro TSH. The identification of macro TSH is a time-consuming and not readily available procedure. It is not recommended that screening be conducted in all patients with mild thyroid abnormalities, but rather to check patients with TSH levels higher than $10 \mathrm{mIU} / \mathrm{L}$ and with normal fT4 and fT3, before hormone replacement therapy is initiated. On the other hand, the estimated cut-off for TSH level is not decisive. There are reports of patients with TSH level lower than 10, in whose blood macro TSH molecules were reported to be found [50,51].

Polyethylene glycol (PEG) precipitation is widely used in everyday clinical practice to diagnose the presence of macroprolactin in patients suffering from hyperprolactinemia [52]. As it was mentioned before, macro TSH has similar properties with macroprolactin and PEG precipitation was transferred to the diagnostic process of macro TSH identification [43]. The presence of macro TSH in a serum sample is suspected when TSH recovery is low; however, the exact cut-off was not clearly estimated. Usually, the percentage of recovery calculation less than 20 or $25 \%$ is used in literature [53, 54]. Although PEG precipitation seems to be an appropriate screening test for the presence of macro TSH, it is inconclusive. When the recovery calculation is low, macro TSH should be detected with gel filtration chromatography (GFC) [50]. Hattori et al. reported that out of 117 patients with low PEG recovery $(<25 \%)$, only in seven was the presence of macro TSH confirmed [43].

It should be noted that human anti-mouse antibodies may also lead to a decrease in the recovery calculation for PEG precipitation. HAMAs are mostly -immunoglobulins, and in GFC they may give similar peaks like macro TSH $[43,44]$. In order to exclude interferences from diagnostic processes and to avoid misclassification, the presence of HAMAs in serum should be tested.

\section{Biotin}

The biotin-streptavidin [55] complex is often used in immunoassays for the determination of TSH, fT3, fT4, and anti-TSHR.

Biotin is a low-molecular-weight vitamin $(\mathrm{H}, \mathrm{B} 7)$, and it is a cofactor for carboxylating enzymes. This molecule easily binds to hormones [56] and antibodies widely used in assays [19]. Because of additional biotin intake, patients have higher concentration of this vitamin in the blood, which may interfere with the assays and lead to false positive or negative results. [19].

The basic diet usually provides about 35 to $70 \mu \mathrm{g}$ of biotin per day [55]. Dietary supplements often contain biotin as a vitamin used to treat hair loss or brittle nails [57]. The doses of biotin recommended by dermatologists are usually approximately $10 \mathrm{mg}$ per day or more [19]. On the Polish market, supplements contain 2.5, 5, or $10 \mathrm{mg}$ of biotin in one tablet.

Furthermore, biotin is also used in the treatment of different disorders, such as: multiple sclerosis, mitochondrial diseases [55], and rare congenital metabolic disorders [58], i.e. biotinidase deficiency, propionic acidosis [59, 60], thiamine transporter-2 deficiency, or deficiency of holocarboxylase synthetase [58].

Due to a low dosage of this vitamin, food supplements containing biotin do not usually cause important laboratory interferences. The problem is usually observed in patients receiving biotin in doses exceeding the recommended intake by e.g. 10,000 times. This may occur in multiple sclerosis therapy, when patients receive doses from 100 to $300 \mathrm{mg}$ of biotin per day [61].

A type of test platform used to determine hormone levels is connected with possible interferences because biotin may affect the measurement of TSH or fT4 and fT3 (or all of them). TSH level may be falsely lowered [56] and fT4, T4 and T3 concentrations - falsely elevated [19]. This laboratory picture imitates thyrotoxicosis, and laboratory interferences should always be taken into consideration before the treatment is initiated, particularly when the patient has no symptoms.

Biotin interferes not only with thyroid function tests but also with many other tests that measure the levels of e.g. troponin I, parathyroid hormone (PTH), oestradiol, testosterone, dehydroepiandrosterone sulphate, luteinising hormone, and 25-hydroxy vitamin D [62]. It is also suspected that tumour marker tests, such as cancer antigen 19.9 (CA 19.9), carcinoembryonic antigen (CEA), and -fetoprotein (AFP), may be affected, but data from the literature are inconsistent $[63,64]$.

The widespread use of the biotin-streptavidin system in immunoassays and more frequent use of dietary supplements or medicaments with high dosage of biotin in patients with various conditions may lead to more frequent occurrence of interferences in clinical practice. It can be avoided by close investigation of the patient's medical history and supplementary intake prior to performing medical tests. It is important to inform the patient about not taking biotin for at least 24 hours before a test. The time interval between biotin intake and the laboratory test should be longer if kidney diseases are present or when biotin is taken in a very high dosage, as 
in neurological diseases [57]. Some authors believe that this period should be extended even to seven days [58].

\section{Anti-streptavidin and anti-ruthenium antibodies}

Anti-streptavidin and anti-ruthenium antibodies are rarely found interferences in TFTs, and they affect immunoassays based on different methods.

As was mentioned before, the biotin-streptavidin interaction is widely used, both in competitive and sandwich immunoassays. The laboratory interferences with biotin seem to be more frequent, and they are specified in a previous part of this paper. There are only a few case studies reporting interferences with anti-streptavidin antibodies in thyroid function tests [65-69], but interferences might also occur in other tests [70].

The clinical picture of interference with anti-streptavidin antibodies is similar to that described in biotin interference. It includes elevated levels of fT4 and fT3 as well as decreased TSH level measured on a test platform using biotin-streptavidin complexes. Positive interference in measurements of antibodies against TSH receptor (anti-TSHR), thyroid peroxidase (anti-TPO) and thyroglobulin (anti-TG) were also reported [66]. Interfered tests results resemble Graves' disease and that may lead to misdiagnosis. If no symptoms of hyperthyroidism are noticed but only laboratory measurements suggest the disorder, interference should be suspected.

There are few methods to eliminate the impact of anti-streptavidin interference on an assay. Testing a serum sample with a different technique (without using biotin-streptavidin complexes) is helpful and usually an easily available method. Furthermore, there are methods designed to identify biotin interference, which were transferred to diagnostic process of anti-streptavidin interference. Incubation of a serum sample with a streptavidin-linked agarose or with streptavidin beads seems to be successfully used in purification of serum from antibodies [67]. In all case reports found in the literature, an aliquot was sent to the company to get a confirmation [65-69].

Ruthenium $(\mathrm{Ru})$ is a chemical element used in some laboratory methods as a label in assays based on electrochemiluminescence.

Anti-ruthenium antibodies rarely affect laboratory testing. The prevalence of this interference was estimated at $<0.1-0.24 \%$ [71]. Those antibodies mostly interfere with fT3 and fT 4 measurements, but there are case reports describing false results of TSH levels [72]. After anti-Ru interference was firstly described in 2007, a next-generation diagnostic procedure was introduced in 2008 and decreased the prevalence of interference, but did not eliminate it completely.

Anti-Ru interference may have a heterogenous clinical picture. Affected assays usually give falsely elevated concentration of fT4 and fT3 and falsely decreased TSH levels [73-75], however, opposite results may also be found $[76,77]$.

Different methods of identification anti-Ru interference was described. The blood sample should be tested with an immunoassay, in which ruthenium is not used as a label. In the case reports, the verification of anti-Ru interference was performed by sending an aliquot to the company that uses this methodology in its assays (Roche Diagnostic) [73-77].

\section{Thyroid hormone autoantibodies (THAAbs)}

The assessment of anti-thyroid antibodies is an important step in the diagnostic process of thyroid diseases. The antibodies most frequently observed in everyday practice, i.e. anti-TSHR, anti-TPO, and anti-TG, do not affect thyroid function tests. Those that may interfere in immunoassays are anti-T4 and anti-T3 antibodies. THAAbs are found in $1.8 \%$ of the general population, but in patients with autoimmune thyroid diseases the prevalence may be much higher [78]. The level of THAAbs increases after a fine-needle aspiration biopsy [79], as well as in other autoimmune diseases (e.g. type 1 diabetes, vitiligo) [80, 81].

Although interference with anti-T4 and anti-T3 antibodies occurs more often in one-step immunoassays, other types of immunoassays may be affected, as well [82]. THAAbs bind to an analyte or a labelled tracer, giving false results. The hormone levels are estimated to be inversely proportional to a signal in the one-step immunoassay. THAAbs reduce the signal by binding to a labelled hormone analogue - total and free $\mathrm{T} 4$ and $\mathrm{T} 3$ concentrations are falsely elevated [82]. It should be noted that THAAbs do not interfere with TSH measurements. When thyroid function is assessed in patients with thyroid hormone autoantibodies present in the blood, TSH seems to be more valuable and reliable [83].

Testing a sample with a different assay and serial dilution are useful methods of identification, but sometimes are insufficient. A more specific method of interference identification is radioimmunoprecipitation. Firstly, a serum sample is incubated with a radiolabelled hormone (or hormone analogue), then it is precipitated with PEG and the precipitate radioactivity is measured [10]. The PEG precipitation, without using radioactivity, may also be used as an easier and more available method [84].

\section{Risk groups for the presence of laboratory interference}

Risk groups for a presence of laboratory interference include:

- patients who previously had discrepancies in laboratory test results or who were diagnosed with laboratory interference in the past; 
- patients who received treatment with anti-animal immunoglobulins in the past, e.g. biological treatment such as rituximab;

- patients with rheumatoid arthritis or with high levels of rheumatoid factor;

- patients who take medicaments containing biotin (especially in high dosage).

\section{Summary}

Signs and symptoms presented by a patient and physical examination still comprise the basis of diagnostic process, whereas laboratory tests are additional elements of a clinical picture and cannot replace it. In subclinical hormonal disorders, a comparison of non-specific symptoms with disturbances in laboratory testing is challenging. However, the awareness of the possibility of laboratory interference should stop us from depending only on laboratory test results, and this may help to reduce the number of false diagnoses and unnecessary therapies. Treatment should be initiated with caution in patients whose TSH levels exceed $10 \mu \mathrm{IU} / \mathrm{mL}$ but whose $\mathrm{TH}$ levels are within range and abnormalities are not seen in thyroid ultrasound examination.

The aim of this article was to direct clinicians' attention to interference in thyroid function tests as an important problem in the diagnostic process. The summary of the influence of different factors on hormonal assays is presented in Figure 3. Avoiding interference is not possible nowadays because any platform used in hormonal assays is free from the influence of external factors. The problem of laboratory interference in hormonal tests should be the subject of deeper reflection and should be discussed more extensively with laboratory diagnosticians to assess its actual range.

\section{Funding}

This publication was prepared under a project financed from the funds granted by the Ministry of Science and Higher Education in the "Regional Initiative of Excellence" program for the years 2019-2022, project number 016/RID/2018/19, the amount of funding 11,998,121.30 PLN, and funds from Wroclaw Medical University (ST937).

\section{References}

1. Thienpont LM, Van Uytfanghe K, Poppe K, et al. Determination of free thyroid hormones. Best Pract Res Clin Endocrinol Metab. 2013; 27(5): 689-700, doi: 10.1016/j.beem.2013.05.012, indexed in Pubmed: 24094639.

2. Fraenkel M, Shafat T, Cahn A, et al. Low thyroid-stimulating hormone and its persistence beyond the first trimester of pregnancy. Int J Gynaecol Obstet. 2018; 142(3): 270-276, doi: 10.1002/ijgo.12540, indexed in Pubmed: 29856070.

3. Adler SM, Wartofsky L. The nonthyroidal illness syndrome. Endocrinol Metab Clin North Am. 2007; 36(3): 657-72, vi, doi: 10.1016/j. ecl.2007.04.007, indexed in Pubmed: 17673123
4. Soh SB, Aw TC. Laboratory Testing in Thyroid Conditions Pitfalls and Clinical Utility. Ann Lab Med. 2019; 39(1): 3-14, doi: 10.3343/alm.2019.39.1.3, indexed in Pubmed: 30215224.

5. Lewandowski KC, Dąbrowska K, Lewiński A. Case report: When measured free T4 and free T3 may be misleading. Interference with free thyroid hormones measurements on Roche $₫$ and Siemens ${ }^{\circledR}$ platforms. Thyroid Res. 2012; 5(1): 11, doi: 10.1186/1756-6614-5-11, indexed in Pubmed: 23107155.

6. Sztefko K. Metody immunochemiczne. In: Solnica B, Sztefko K. ed. Medyczne laboratorium diagnostyczne. Metodyka i aparatura. PZWL, Warszawa 2015: 135-162.

7. Gurnell M, Halsall DJ, Chatterjee VK. What should be done when thyroid function tests do not make sense? Clin Endocrinol (Oxf) 2011; 74(6): 673-678, doi: 10.1111/j.1365-2265.2011.04023.x, indexed in Pubmed: 21521292

8. Haddad RA, Giacherio D, Barkan AL. Interpretation of common endocrine laboratory tests: technical pitfalls, their mechanisms and practical considerations. Clin Diabetes Endocrinol. 2019; 5: 12, doi: 10.1186/s40842-019-0086-7, indexed in Pubmed: 31367466.

9. Fillée C, Cumps J, Ketelslegers JM. Comparison of three free T4 (FT4) and free T3 (FT3) immunoassays in healthy subjects and patients with thyroid diseases and severe non-thyroidal illnesses. Clin Lab. 2012; 58(7-8): 725-736, indexed in Pubmed: 22997973.

10. Srichomkwun P, Scherberg NH, Jakšić J, et al. Diagnostic Dilemma in Discordant Thyroid Function Tests Due to Thyroid Hormone Autoantibodies. AACE Clin Case Rep. 2017; 3(1): e22-e25, doi: 10.4158/EP151142. CR, indexed in Pubmed: 28078322

11. Vandendriessche B, Lapauw B, Kaufman JM, et al. A practical approach towards the evaluation of aberrant thyroid function tests. Acta Clin Belg. 2020; 75(2): 155-162, doi: 10.1080/17843286.2019.1577531, indexed in Pubmed: 30806594

12. Hawker C. Radioimmunoassay and Related Methods. Analyt Chem. 2012; 45(11), doi: 10.1021/ac60333a722.

13. Kohl TO, Ascoli CA. Immunoassays. Cold Spring Harb Protoc. 2017; 2017(7): pdb.top093690, doi: 10.1101/pdb.top093690, indexed in Pubmed: 28679720.

14. Hicks JM. Fluorescence immunoassay. Hum Pathol. 1984; 15(2): 112-116, doi: 10.1016/s0046-8177(84)80049-0, indexed in Pubmed: 6365732.

15. Cinquanta L, Fontana DE, Bizzaro N. Chemiluminescent immunoassay technology: what does it change in autoantibody detection? Auto Immun Highlights. 2017; 8(1): 9, doi: 10.1007/s13317-017-0097-2, indexed in Pubmed: 28647912.

16. Guo Z, Sha Y, Hu Y, et al. In-electrode vs. on-electrode: ultrasensitive Faraday cage-type electrochemiluminescence immunoassay. Chem Commun (Camb). 2016; 52(25): 4621-4624, doi: 10.1039/c6cc00787b, indexed in Pubmed: 26861844

17. Mock DM, deLorimer AA, Liebman WM, et al. Biotin deficiency: an unusual complication of parenteral alimentation. N Engl J Med. 1981; 304(14): 820-823, doi: 10.1056/NEJM198104023041405, indexed in Pubmed: 6782478 .

18. Diamandis EP, Christopoulos TK. The biotin-(strept)avidin system: principles and applications in biotechnology. Clin Chem. 1991; 37(5): 625-636, indexed in Pubmed: 2032315.

19. Sathyanarayana Rao TS, Christopher R, Andrade C. Biotin supplements and laboratory test results in neuropsychiatric practice and research. Indian J Psychiatry. 2017; 59(4): 405-406, doi: 10.4103/psychiatry.IndianJPsychiatry_454_17, indexed in Pubmed: 29497180.

20. Sarkar R. TSH Comparison Between Chemiluminescence (Architect) and Electrochemiluminescence (Cobas) Immunoassays: An Indian Population Perspective. Indian J Clin Biochem. 2014; 29(2): 189-195, doi: 10.1007/s12291-013-0339-7, indexed in Pubmed: 24757301.

21. Czerwińska E, Marcinowska-Suchowierska E. Interpretacja badań tyreologicznych w praktyce lekarza rodzinnego. Post Nauk Med. 2007; 4: 139-143.

22. Favresse J, Burlacu MC, Maiter D, et al. Interferences With Thyroid Function Immunoassays: Clinical Implications and Detection Algorithm. Endocr Rev. 2018; 39(5): 830-850, doi: 10.1210/er.2018-00119, indexed in Pubmed: 29982406

23. Koulouri O, Moran C, Halsall D, et al. Pitfalls in the measurement and interpretation of thyroid function tests. Best Pract Res Clin Endocrinol Metab. 2013; 27(6): 745-762, doi: 10.1016/j.beem.2013.10.003, indexed in Pubmed: 24275187.

24. Tate J, Ward G. Interferences in immunoassay. Clin Biochem Rev. 2004; 25(2): 105-120, indexed in Pubmed: 18458713.

25. Bjerner J, Nustad K, Norum LF, et al. Immunometric assay interference: incidence and prevention. Clin Chem. 2002; 48(4): 613-621, indexed in Pubmed: 11901059.

26. Lam L, Bagg W, Smith G, et al. Apparent Hyperthyroidism Caused by Biotin-Like Interference from IgM Anti-Streptavidin Antibodies. Thyroid. 2018; 28(8): 1063-1067, doi: 10.1089/thy.2017.0673, indexed in Pubmed: 29808739. 
27. Ismail AA, Barth JH. Wrong biochemistry results. BMJ. 2001; 323(7315): 705-706, doi: 10.1136/bmj.323.7315.705, indexed in Pubmed: 11576963

28. Ismail AAA. On the diagnosis of subclinical hypothyroidism. Br J Gen Pract. 2007; 57(545): 1000-1001, doi: 10.3399/096016407782604802, indexed in Pubmed: 18252087.

29. Astarita G, Gutiérrez S, Kogovsek N, et al. False positive in the measurement of thyroglobulin induced by rheumatoid factor. Clin Chim Acta. 2015; 447: 43-46, doi: 10.1016/j.cca.2015.04.039, indexed in Pubmed: 25979693.

30. Giovanella L, Keller F, Ceriani L, et al. Heterophile antibodies may falsely increase or decrease thyroglobulin measurement in patients with differentiated thyroid carcinoma. Clin Chem Lab Med. 2009; 47(8): 952-954, doi: 10.1515/CCLM.2009.230, indexed in Pubmed: 19589101.

31. Bolstad N, Warren DJ, Nustad K. Heterophilic antibody interference in immunometric assays. Best Pract Res Clin Endocrinol Metab. 2013; 27(5): 647-661, doi: 10.1016/j.beem.2013.05.011, indexed in Pubmed 24094636.

32. Kaplan I, Levinson S. When Is a Heterophile Antibody Not a Heterophile Antibody? When It Is an Antibody against a Specific Immunogen. Clin Chem. 1999; 45(5): 616-618, doi: 10.1093/clinchem/45.5.616, indexed in Pubmed: 10222346.

33. Kricka L. Human Anti-Animal Antibody Interferences in Immunological Assays [published correction appears in Clin Chem 2000 Oct; 46(10): 1722]. Clin Chem. 1999; 45(7): 942-956, doi: 10.1093/clinchem/45.7.942, indexed in Pubmed: 10388468

34. Chin KP, Pin YC. Heterophile antibody interference with thyroid assay. Intern Med. 2008; 47(23): 2033-2037, doi: 10.2169/internalmedicine.47.1496, indexed in Pubmed: 19043256.

35. Nishimura K, Sugiyama D, Kogata Y, et al. Meta-analysis: diagnostic accuracy of anti-cyclic citrullinated peptide antibody and rheumatoid factor for rheumatoid arthritis. Ann Intern Med. 2007; 146(11): 797-808, doi: 10.7326/0003-4819-146-11-200706050-00008, indexed in Pubmed: 17548411.

36. Norden AG, Jackson RA, Norden LE, et al. Misleading results from immunoassays of serum free thyroxine in the presence of rheumatoid factor. Clin Chem. 1997; 43 (6 Pt 1): 957-962, indexed in Pubmed: 9191546.

37. Lupoli GA, Barba L, Liotti A, et al. Falsely elevated thyroglobulin and calcitonin due to rheumatoid factor in non-relapsing thyroid carcinoma: A case report. Medicine (Baltimore). 2019; 98(5): e14178, doi: 10.1097/MD.0000000000014178, indexed in Pubmed: 30702570.

38. Georges A, Charrié A, Raynaud S, et al. Thyroxin overdose due to rheumatoid factor interferences in thyroid-stimulating hormone assays. Clin Chem Lab Med. 2011; 49(5): 873-875, doi: 10.1515/CCLM.2011.144, indexed in Pubmed: 21303295.

39. Ismail AAA. Interference from endogenous antibodies in automated immunoassays: what laboratorians need to know. J Clin Pathol. 2009; 62(8): 673-678, doi: 10.1136/jcp.2008.055848, indexed in Pubmed: 19638536

40. Ismail AAA, Walker PL, Barth JH, et al. Wrong biochemistry results: two case reports and observational study in 5310 patients on potentially misleading thyroid-stimulating hormone and gonadotropin immunoassay results. Clin Chem. 2002; 48(11): 2023-2029, indexed in Pubmed: 12406989.

41. Sturgeon CM, Viljoen A. Analytical error and interference in immunoassay: minimizing risk. Ann Clin Biochem. 2011; 48(Pt 5): 418-432 doi: 10.1258/acb.2011.011073, indexed in Pubmed: 21750113.

42. Ismail AAA. A radical approach is needed to eliminate interference from endogenous antibodies in immunoassays. Clin Chem. 2005; 51(1): 25-26, doi: 10.1373/clinchem.2004.042523, indexed in Pubmed: 15539464

43. Hattori N, Ishihara T, Yamagami K, et al. Macro TSH in patients with subclinical hypothyroidism. Clin Endocrinol (Oxf). 2015; 83(6): 923-930, doi: 10.1111/cen.12643, indexed in Pubmed: 25388002.

44. Hattori N, Ishihara T, Matsuoka N, et al. Anti-Thyrotropin Autoantibodies in Patients with Macro-Thyrotropin and Long-Term Changes in Macro-Thyrotropin and Serum Thyrotropin Levels. Thyroid. 2017 27(2): 138-146, doi: 10.1089/thy.2016.0442, indexed in Pubmed: 27785976.

45. Spitz IM, Le Roith D, Hirsch H, et al. Increased high-molecular-weight thyrotropin with impaired biologic activity in a euthyroid man. N Eng J Med. 1981; 304(5): 278-282, doi: 10.1056/NEJM198101293040506, indexed in Pubmed: 6255331

46. Smith TP, Suliman AM, Fahie-Wilson MN, et al. Gross variability in the detection of prolactin in sera containing big big prolactin (macroprolactin) by commercial immunoassays. J Clin Endocrinol Metab. 2002; 87(12): 5410-5415, doi: 10.1210/jc.2001-011943, indexed in Pubmed: 12466327.

47. Mills F, Jeffery J, Mackenzie P, et al. An immunoglobulin G complexed form of thyroid-stimulating hormone (macro thyroid-stimulating hormone) is a cause of elevated serum thyroid-stimulating hormone concentration. Ann Clin Biochem. 2013; 50(Pt 5): 416-420, doi: 10.1177/0004563213476271, indexed in Pubmed: 23828944

48. Biondi B, Cooper DS, Biondi B, et al. Subclinical Hypothyroidism: A Review. JAMA. 2019; 322(2): 153-160, doi: 10.1001/jama.2019.9052, indexed in Pubmed: 31287527.
49. Pearce SHS, Brabant G, Duntas LH, et al. 2013 ETA Guideline: Management of Subclinical Hypothyroidism. Eur Thyroid J. 2013; 2(4): 215-228, doi: 10.1159/000356507, indexed in Pubmed: 24783053.

50. Hattori N, Ishihara T, Shimatsu A. Variability in the detection of macro TSH in different immunoassay systems. Eur J Endocrinol. 2016; 174(1): 9-15, doi: 10.1530/EJE-15-0883, indexed in Pubmed: 26438715.

51. Verhoye E, Van den Bruel A, Delanghe JR, et al. Spuriously high thyrotropin values due to anti-thyrotropin antibodies in adult patients. Clin Chem Lab Med. 2009; 47(5): 604-606, doi: 10.1515/CCLM.2009.138, indexed in Pubmed: 19397486.

52. Vieira JG, Tachibana TT, Obara LH, et al. Extensive experience and validation of polyethylene glycol precipitation as a screening method for macroprolactinemia. Clin Chem. 1998; 44(8 Pt 1): 1758-1759, indexed in Pubmed: 9702971.

53. Mills F, Jeffery J, Mackenzie P, et al. An immunoglobulin G complexed form of thyroid-stimulating hormone (macro thyroid-stimulating hormone) is a cause of elevated serum thyroid-stimulating hormone concentration. Ann Clin Biochem. 2013; 50(Pt 5): 416-420, doi: 10.1177/0004563213476271, indexed in Pubmed: 23828944

54. Loh TP, Kao SL, Halsall DJ, et al. Macro-thyrotropin: a case report and review of literature. J Clin Endocrinol Metab. 2012; 97(6): 1823-1828, doi: 10.1210/jc.2011-3490, indexed in Pubmed: 22466337.

55. Gifford JL, Sadrzadeh H, Naugler C. Biotin interference Underrecognized patient safety risk in laboratory testing. Can Fam Physician. 2018; 64(5): 370, indexed in Pubmed: 29760259.

56. Elston MS, Sehgal S, Du Toit S, et al. Factitious Graves' Disease Due to Biotin Immunoassay Interference-A Case and Review of the Literature. J Clin Endocrinol Metab. 2016; 101(9): 3251-3255, doi: 10.1210/jc.2016-1971, indexed in Pubmed: 27362288.

57. Piketty ML, Polak M, Flechtner I, et al. False biochemical diagnosis of hyperthyroidism in streptavidin-biotin-based immunoassays: the problem of biotin intake and related interferences. Clin Chem Lab Med. 2017; 55(6): 780-788, doi: 10.1515/cclm-2016-0606, indexed in Pubmed: 27732554

58. Ostrowska M, Bartoszewicz Z, Bednarczuk T, et al. The effect of biotin interference on the results of blood hormone assays. Endokrynol Pol. 2019; 70(1): 102-121, doi: 10.5603/EP.a2018.0084, indexed in Pubmed: 30855699.

59. Kwok JS, Chan IS, Chan MM. Biotin interference on TSH and free thyroid hormone measurement. Pathology. 2012; 44(3): 278-280, doi: 10.1097/pat.0b013e3283514002, indexed in Pubmed: 22437752.

60. Wijeratne NG, Doery JCG, Lu ZX. Positive and negative interference in immunoassays following biotin ingestion: a pharmacokinetic study. Pathology. 2012; 44(7): 674-675, doi: 10.1097/PAT.0b013e32835a3c17, indexed in Pubmed: 23089740.

61. Minkovsky A, Lee MN, Dowlatshahi M, et al High-dose biotin treatmen for secondary progressive multiple sclerosis may interfere with thyroid assays. AACE Clin Case Rep. 2016; 2(4): e370-e373, doi: 10.4158/EP161261. CR, indexed in Pubmed: 27917400

62. Koehler V, Mann U, Nassour A, et al. Fake news? Biotin interference in thyroid immunoassays. Clin Chim Acta. 2018; 484: 320-322, doi: 10.1016/j. cca.2018.05.053, indexed in Pubmed: 29856977.

63. Li J, Wagar EA, Meng QH. Comprehensive assessment of biotin interference in immunoassays. Clin Chim Acta. 2018; 487: 293-298, doi: 10.1016/j. cca.2018.10.013, indexed in Pubmed: 30296442.

64. Trambas C, Lu Z, Yen T, et al. Characterization of the scope and magnitude of biotin interference in susceptible Roche Elecsys competitive and sandwich immunoassays. Ann Clin Biochem. 2018; 55(2): 205-215 doi: 10.1177/0004563217701777, indexed in Pubmed: 28875734

65. Favresse J, Lardinois B, Nassogne MC, et al. Anti-streptavidin antibodies mimicking heterophilic antibodies in thyroid function tests. Clin Chem Lab Med. 2018; 56(7): e160-e163, doi: 10.1515/cclm-2017-1027, indexed in Pubmed: 29447115.

66. Peltier L, Massart C, Moineau MP, et al. Anti-streptavidin interferences in Roche thyroid immunoassays: a case report. Clin Chem Lab Med. 2016; 54(1): e11-e14, doi: 10.1515/cclm-2015-0350, indexed in Pubmed: 26154194.

67. Rulander NJ, Cardamone D, Senior M, et al. Interference from an ti-streptavidin antibody. Arch Pathol Lab Med. 2013; 137(8): 1141-1146, doi: 10.5858/arpa.2012-0270-CR, indexed in Pubmed: 23899071.

68. Harsch IA, Konturek PC, Böer K, et al. Implausible elevation of peripheral thyroid hormones during therapy with a protein supplement. Clin Chem Lab Med. 2017; 55(9): e197-e198, doi: 10.1515/cclm-2016-1015, indexed in Pubmed: 28076312

69. Bayart JL, Favresse J, Melnik E, et al. Erroneous thyroid and steroid hormones profile due to anti-streptavidin antibodies. Clin Chem Lab Med. 2019; 57(10): e255-e258, doi: 10.1515/cclm-2018-1355, indexed in Pubmed: 30903751

70. Berth M, Willaert S, De Ridder C. Anti-streptavidin IgG antibody interference in anti-cyclic citrullinated peptide (CCP) IgG antibody assays is a rare but important cause of false-positive anti-CCP results. Clin Chem Lab Med. 2018; 56(8): 1263-1268, doi: 10.1515/cclm-2017-1153, indexed in Pubmed: 29466233. 
71. Sapin R, Agin A, Gasser F. Efficacy of a new blocker against anti-ruthenium antibody interference in the Elecsys free triiodothyronine assay. Clin Chem Lab Med. 2007; 45(3): 416-418, doi: 10.1515/CCLM.2007.064, indexed in Pubmed: 17378744.

72. Ando T, Yasui JI, Inokuchi N, et al. Non-specific activities against ruthenium crosslinker as a new cause of assay interference in an electrochemilluminescent immunoassay. Intern Med. 2007; 46(15): 1225-1229, doi: 10.2169/internalmedicine.46.0188, indexed in Pubmed: 17675774.

73. Buijs MM, Gorgels JP, Endert E. Interference by antiruthenium antibodies in the Roche thyroid-stimulating hormone assay. Ann Clin Biochem. 2011; 48(Pt 3): 276-281, doi: 10.1258/acb.2010.010160, indexed in Pubmed: 21441394.

74. Heijboer AC, Ijzerman RG, Bouman AA, et al. Two cases of antiruthenium antibody interference in Modular free thyroxine assay. Ann Clin Biochem. 2009; 46(Pt 3): 263-264, doi: 10.1258/acb.2009.008258, indexed in Pubmed: 19261677.

75. Ohba K, Noh JY, Unno T, et al. Falsely elevated thyroid hormone levels caused by anti-ruthenium interference in the Elecsys assay resembling the syndrome of inappropriate secretion of thyrotropin. Endocr J. 2012; 59(8): 663-667, doi: 10.1507/endocrj.ej12-0089, indexed in Pubmed: 22673200.

76. Favresse J, Paridaens H, Pirson N, et al. Massive interference in free $\mathrm{T} 4$ and free T3 assays misleading clinical judgment. Clin Chem Lab Med. 2017; 55(4): e84-e86, doi: 10.1515/cclm-2016-0255, indexed in Pubmed: 27665421.

77. Suarez Rivero R, Ponce Lorenzo F, Díaz Torres J, et al. Falsely elevated thyroid-stimulating hormone value due to anti-ruthenium antibodies in a patient with primary hypothyroidism: a case report. Clin Chem Lab Med. 2017; 55(12): e273-e275, doi: 10.1515/cclm-2016-0515, indexed in Pubmed: 28598794

78. Sakata S, Matsuda M, Ogawa T, et al. Prevalence of thyroid hormone autoantibodies in healthy subjects. Clin Endocrinol (Oxf). 1994; 41(3): 365-370, doi: 10.1111/j.1365-2265.1994.tb02558.x, indexed in Pubmed: 7955443.

79. Benvenga S, Bartolone L, Squadrito S, et al. Thyroid hormone autoantibodies elicited by diagnostic fine needle biopsy. J Clin Endocrinol Metab. 1997; 82(12): 4217-4223, doi: 10.1210/jcem.82.12.4420, indexed in Pubmed: 9398743.

80. Benvenga S, Pintaudi B, Vita R, et al. Serum thyroid hormone autoantibodies in type 1 diabetes mellitus. J Clin Endocrinol Metab. 2015; 100(5) 1870-1878, doi: 10.1210/jc.2014-3950, indexed in Pubmed: 25710564.

81. Kemp EH. Antithyroid hormone autoantibodies in vitiligo. Br J Dermatol. 2014; 171(4): 690, doi: 10.1111/bjd.13317, indexed in Pubmed: 25319423.

82. Zouwail SA, O'Toole AM, Clark PMS, et al. Influence of thyroid hormone autoantibodies on 7 thyroid hormone assays. Clin Chem. 2008; 54(5): 927-928, doi: 10.1373/clinchem.2007.099770, indexed in Pubmed: 18443182

83. Allan DJ, Murphy F, Needham CA, et al. Sensitive test for thyroid hormone autoantibodies in serum. Lancet. 1982; 2(8302): 824, doi: 10.1016/s0140-6736(82)92716-7, indexed in Pubmed: 6126696.

84. Massart C, Elbadii S, Gibassier J, et al. Anti-thyroxine and anti-triiodothyronine antibody interferences in one-step free triiodothyronine and free thyroxine immunoassays. Clin Chim Acta. 2009; 401(1-2): 175-176, doi: 10.1016/j.cca.2008.11.001, indexed in Pubmed: 19028480. 